\section{English Language Teaching Materials and Cross-Cultural Understanding: Are There Bridges or Divides?}

\author{
Jayakaran Mukundan \\ Universiti Putra Malavsia
}

by that critical incident cited in Paul Simon's book The Tongue-Tied American (1980). In that book Simon recounts the incident where a member of the Georgia school board approached Genelle Morain of the University of Georgia with the question: "Why should a student who will never leave Macon, Georgia, study a foreign language?" Her reply to that question was: "That's why he should study another language" (p.76). In Malaysia likewise, some politicians (in the 3 decades after independence) even questioned the need for English as an important second language. Obviously these people believed that Malaysians would live as they would, depending on the first language (Bahasa Melayu) for their work needs. But all that changed with the burst of work in computer-related industry. There was a huge need for people who could communicate in English effectively as the country became more dependent on the international community for business. Today young Malaysians not only have to deal with international businessmen in the country, they frequently make overseas trips for business purposes. The problem of finding enough Malaysians competent enough to do business in English and compete with their counterparts in developing countries led to a drastic change in the School Curriculum. Today the teaching of Mathematics and Science in both Primary and Secondary schools is done in English, so as to provide the immersion into English in the early years.

There are many people who now increasingly believe that culture should be taught within the language curriculum. The new foreign language standards (Standards 1996), emphasizes the need to "integrate" it within the new language curriculum. The importance for teaching culture is widely believed to promote greater cross-cultural understanding. The most important reason, however for most people as to why culture should be integrated within language curriculums, is, because language and culture are inseparably intertwined.

The world is getting smaller by the day and the concept of the "borderless world" has become a reality to such an extent that the very people who scoffed at the idea are beginning to take it seriously. In Malaysia the rapid modernization that has come about through industrialization has made the country become very attached to the English language, a language that is crucial for international trade. The situation in the past can best be illustrated 
WHAT CAN BE THE PROBLEMS IF CULTURE IS NOT INTEGRATED INTO LANGUAGE WITHIN TEACHING MATERIAL?

There will be several problems that we can anticipate if culture is not integrated into teaching material. Some of the more serious ones will include:

1. The inability of learners to fully assimilate meaning within contexts of language use

2. The inability of the material to promote "realism"

3. The inability of the material to bring about "immersion" into the new world which will leave bias, stereotyping and prejudice behind

In the next section of this paper, the writer will illustrate with examples of how each of the three problems come about and the implications of this on materials within the learning-teaching situation. Suggestions will also be provided on how culture can be integrated into language teaching materials.

\section{THE INABILITY OF LEARNERS TO FULLY ASSIMILATE MEANING WITHIN CONTEXTS OF LANGUAGE USE}

Language teaching has in most parts of the history of ELT been nothing but focus on exercises presenting language for practice in make-belief situations. But not many people realize the folly of excessive focus on analytic or studial as opposed to experiential learning. The weaknesses of excessive focus on analytical methods was exposed as early as in 1904 by Jesperson in his text "How to teach a foreign language", where he said that "we ought to learn a language through sensible communications" (p.11). What Jesperson wanted was for teachers to move away from language practice on random lists of disconnected sentences to discourse which is connected to thoughts communicated. This 1904 exposure by Jesperson was too far ahead of its time and the period of Practice, Practice, Practice went full steam ahead, for seventy five years, until after Widdowson (1978) and Slager (1978) reemphasized the need for "context" and "longer, more natural discourse" as a basis for language teaching. What Widdowson and Slager advocated was teaching which totally put a stop to, or paid minimal emphasis on monotonous drills and endless repetitions. They revealed that our textbooks are filled with exercises which have students do drills on disconnected sentences. A negative aspect of these exercises is that they are unnatural and contrived. None of these utterances are rarely ever heard within the local and the native speaker situation. A typical example of a short dialogue practicing forms and functions associated to making polite requests within a textbook would have two people in limited roles such as this:

\section{Dialogue A}

John : I'm going to have a cup of coffee.

Janet : Can you please get me a cup of coffee too,

John : How much sugar do you want in your coffee?

Janet : I'll have two spoonfuls of sugar

John : Do you want any milk in your coffee?

Janet : Yes please. Just a little.

The above example is typical of dialogues in school textbooks, which basically achieve what it sets out to do; which is confine dialogue practice to two person interactions in an office, have the players roll out utterances without any of the interferences that come with natural discourse and hopefully let all these register in the heads of learners after sessions of practice. Most teachers are unaware that "textbook language" as in the example above put learners at a distinct disadvantage when they are faced with interaction with native speakers. In most situations, especially at the workplace, the language is dynamic. A close match to an office situation where natural language would be used would be one such as this:

\section{Dialogue B}

John : I'm going down for a cup of coffee.

Janet : Please John, one for me.

John : White or Black?

Janet : White and two sugars please

Steven : (interrupting) Aaahem... I heard that. I thought you said you were on a diet.

Janet : But that new coffee downstairs is so bitter without sugar

John : OK two sugars Janet

Steven : Can I have a cup too. Black, and no sugar

John : I have only two hands Steven. Go get your own. 
The difference between dialogue $A$ and dialogue $B$ is that $B$ is longer and is closer to natural conversation with interruptions, and all the other peripheral aspects of natural discourse which include things like hesitations. Dialogue $B$ is also closer to the type of discourse that native speakers and near-native speakers engage in. If the objectives of a language curriculum are geared at getting learners to master the language so that they achieve at least near native speaker competencies or even close to that, then the language as represented in Dialogue B should be more common in ELT materials. But is this possible with space constraints in ELT textbooks and coursebooks? Most probably not. But there are ways to overcome this problem of space constraints and one way is to not treat the textbook as the only source of material for teaching. Experts in materials development now say that the core material for teaching (in most cases the textbook) should cater for exercises that focus on language forms while peripheral material (like audio CDs and CD-ROMs and videos) should focus on authentic materials with openended interactive communication. In this way both analytic and experiential aspects of learning merge. Stern (1990:99) explains that an analytic approach is one in which the language is the object of the study, and an experiential approach is one in which the language is learned in communication. Allen et al. (1990:77) feel that these two types of teaching may be complementary and would "provide essential support for one another in the L2 classroom". An analytic focus in teaching decontextualizes linguistic features to allow for isolation of the forms for analysis and practice. The forms under study however should be recontextualized by means of experiential approaches. Recontextualization can be achieved if teachers provide activities using language which not only involves grammar but also the functional, organizational and sociolinguistic aspects of the target language. One way recontextualization can be a reality in classrooms would be by getting students to view scenes in videos and CD-ROMs where natural communication which incorporates the culture of the target language is taking place, after they have had analytical exposure to the forms of the language.

\section{THE INABILITY OF THE MATERIAL TO PROVIDE "REALISM"}

Textbooks are a cultural disaster in terms of realism. Most of the time, they not only neglect representation of the culture of the target language, they in fact have established themselves into a variety of language that is distinctively independent-one which can be regarded as "textbook culture". Some teachers regard textbooks as breaking rules of natural language use as they lack in both situational and linguistic realism. When texts lack in realism of this nature, they are detached from not only the culture of the target language but the first language as well.

Situational realism is achieved in materials if two main criteria are fulfilled; age and interest. This would mean that texts and tasks relate to the age and interests of the target learners. Most often then not, the culture (from the perspective of the broader sense of the word) of target learners, while they vary across boundaries will have commonalities, especially if one looks at the "common behavior related to developmental stages" and associates that with the "culture of learners and learning". We are well aware of what has been written about the predictable psychology of young adult learners from research done extensively in the past, but unfortunately very little of that translates to realism in materials for ELT. Textbook writers blatantly ignore the "culture" of young adult learners by constantly falsifying culture. Texts and activities rarely account for such behavior as teenage restlessness and rebelliousness, the end result of which our textbooks lack in situational realism. Some examples of this found in Malaysian secondary school textbooks are illustrated below in Dialogues $\mathrm{C}$ and $\mathrm{D}$ :

\section{Dialogue C}

School setting

Aminah and Siew Ling are in the school compound

Aminah : Look Siew Ling, the whole garden is full of fallen leaves.

Siew Ling : Yes. It does not look very nice.

Aminah : Our gardener, En. Ahmad is ill. He cannot come to work today. siew Ling: Why don't we get some more friends and do the work for him. Aminah : That's a good idea. Let's go. 


\section{Dialogue D}

\section{School setting}

Chiew Hong is with her father in the school canteen.

Chiew Hong : Father, this is our school canteen.

Father : Oh, its very nice. I am sure they have delicious food here.

Chiew Hong : Yes father, but my favorite is Penang Laksa. It only costs one ringgit.

Father : That is cheap. Lets have Penang Laksa.

Chiew Hong : Thank you father.

Father : Your school canteen is very good. It is also very clean.

Dialogues such as these are common in systems where the agenda for "moral indoctrination" is so strong that it encompasses the entire school curriculum. The sum effect of this approach however would be a lack of interest in the dialogues which, from the onset of the lesson would lead to low motivation levels thus raising resistance to material. If ever there was terminology created today, the one most apt to describe texts such as the ones above would be "pedagogical put-offs"! Excess concern with moral issues, have led material builders to create "mirages" of life. In the two scenes above, the young adult characters show very little sign that they are typical young adults. In fact, they look like clones of the so far unattainable "perfect young adult"; what some circles within society want out of young adults. In typical situations involving young adults, the girls in Dialogue $\mathrm{C}$ would not have easily volunteered to do the cleaning job, and the young adult in Dialogue D would not be playing the "dutiful guide" to the father. Also, striking a conversation on a school canteen is hardly ever done by fathers and teenaged daughters!

Another way in which realism becomes detached from teaching material is when the language of dialogues is made to look artificial. It is true that materials which are deficient in naturalness lack in "linguistic realism". An example of a typical dialogue lacking in linguistic realism found in school textbooks is provided below, in Dialogue $\mathrm{E}$ :

\section{Dialogue E}

Telephone conversation between Ahmad and Chong

Ahmad : Hello is that Chong?

Chong : Yes, this is Chong.

Ahmad : Chong, this is Ahmad.

Chong : Hi Ahmad. How are you?

Ahmad : Fine thank you. And how about you?

Chong : I am fine too.

Ahmad : I called to find about our History homework. Are you doing it now?

Chong : Yes, I am doing the homework now. There is a lot of work to do.

Ahmad : I am not sure which exercise to do. Do we have to do Exercise 2?

Chong : Yes. We have to do Exercise 2.

Ahmad : Do we have to do Exercise 3?

Chong : Yes, we have to do Exercise 3.

Ahmad : Do we write the answers in the textbook?

Chong : Yes, teacher wants us to write the answers in the textbook.

Ahmad : Do we write in pencil?

Chong : Yes, we have to write the answers in pencil.

Some teachers and material builders would consider dialogues such as the one above "necessary" for focused practice as the aim of these exercises would be to provide target structures with minimum obstruction from peripheral or intruding structures that are normally associated with authentic or near-authentic dialogues. While practice such as this with "intensified focus" on target structures may provide practice, they may never lead to learning as narrow intensified practice only enables these structures to be retained in short-term memory. The biggest set back to classroom teaching that materials such as these inflict on learners is the "falseness" of language. Speakers of English, both native or non-native speakers do not "interrogate" their friends over the telephone about homework as the dialogue above suggests. In most cases young adults do not even bother asking each other about how they are, especially since they meet in class everyday. While the aim of such a dialogue would be to teach the affirmative, there are negative consequences that come about from using texts of this nature. Second language 
learners are not exposed to "real" language and this may inhibit their development as proficient users of the language.

\section{THE INABILITY OF THE MATERIAL TO BRING ABOUT "IMMERSION" INTO THE NEW WORLD WHICH WILL LEAVE BIAS, STEREOTYPING AND PREJUDICE BEHIND}

Most people, especially teachers would assume that "cultural immersion" takes care of itself when learners are taught a second or foreign language. This however has been considered myth after recent studies (Hinkel, 1996; Hymes, 1996) showed that Non-native speakers (NNS) in colleges and universities in the United States and Canada and other English-speaking countries "do not always follow the norms of politeness and appropriateness commonly accepted in their L2 communities despite having lived in those countries for several years" (Hinkel, 2001). Textbooks used in Second language (SL) and Foreign Language (FL) situations do not gradually expose learners to sociocultural variables in language and as such mastery of linguistic form alone can lead to disastrous consequences when NNS face NS counterparts.

What makes a particular expression or speech act situationally appropriate is not so much the linguistic form or the range of the speaker's linguistic repertoire, but the sociocultural variables, which are rarely addressed in explicit instruction. Partly for this reason, it is not uncommon to hear ESL learners say How is it going. What's up, or Later to peers, professors, and even university deans (Hinkel, 2001: 448).

University professors in the United States for instance also constantly complain about "unprepared" NNS in tutorials when academic reading is assigned to them. While Native Speakers (NS) master the reading (as they are aware of task demands), NNS are unaware of the implicit nature of the task which demands absolute mastery of the assigned reading. As a result of their lack of preparation, these NNS will give the professors negative impressions of their academic skills and preparation.

Learners' awareness of target language culture in most cases is also lacking and this is true even for advanced and proficient learners. Byram and Morgan (1994: 43) point out learners cannot transform, or accommodate or even effectively assimilate into other culture. They "cannot simply shake off their own culture and step into another". In the case of Mainland Chinese, their strong tradition of copying from their teachers and texts (because they are "perfect") will be viewed as "plagiarism" from the perspective of American culture. Many students from Mainland China are viewed as "cheats" by their peers and teachers because of their inability to step into the culture of the target language. The developers of their ELT material failed to see the importance of exposing them to this aspect of "learning culture" which is prevalent in NS learning environments.

\section{IMPLICATIONS TO MATERIALS DEVELOPMENT AND TEACH-} ING

There is no need for drastic curriculum revamps when attempting to introduce target language culture into target language materials. All it needs is a little direction towards immersion into target language culture. Lafayette $(1978,1988)$ suggests 9 ways in which language and culture can be integrated.

1. Cultural lessons and activities need to be planned as carefully as language activities and integrated into lesson plans.

2. Present cultural topics in conjunction with related thematic units and closely related grammatical content whenever possible. Use cultural contexts for language-practice activities, including those that focus on particular grammatical forms.

3. Use a variety of techniques for teaching culture that involve speaking, listening, reading, and writing skills. Do not limit cultural instruction to lecture or anecdotal formats.

4. Make good use of textbook illustrations and photos. Use probing questions to help students describe and analyze the cultural significance of photos and realia.

5. Use cultural information when teaching vocabulary. Teach students about the connotative meaning of new words. Group vocabulary into culture-related clusters.

6. Use small-group techniques, such as discussions, brainstorming, and role-plays, for cultural instruction. 
7. Avoid a "facts only" approach by including experiential and process learning wherever possible.

8. Use the target language whenever possible to teach cultural content.

9. Test cultural understanding as carefully as language is tested.

The 9 ways suggested above clearly show that the teacher's initiative will go a long way into immersing learners into the culture of the target language. While there is very little that can be done to incorporate culture into textbooks, mainly because of the constraints of space and nationalistic demands, teachers should bring into classrooms photos, pictures, audio tapes and video clips to emphasize language and culture in target language contexts.

\section{CONCLUSION}

The teaching of a language must be accompanied by the culture that surrounds it. The most unfortunate part of "target language culture cleansing" in ELT materials is that materials developers and teachers maliciously equate target language culture to extreme and often immoral sides of life, hence incompatible with the culture of the first language (L1). This misconception must be corrected so that the positive aspects of culture in the target language, those aspects which aid communication and tolerance will find their natural place in the learning of the target language and learners benefit from this.

\section{REFERENCES}

Allen, P; Mervill, S; Birgit, H. and Cummins, J. (1990). Aspects of Classroom Treatment: Toward a More Comprehensive View of Second Language Education. In Harley, B; Allen, P; Cummins, J; and Swain, M. (Eds.). The Development of Second Language Proficiency. Cambridge: Cambridge University Press.

Byram, M and Morgan, C. 1994. Teaching and Learning Culture. Clevedon, UK: Multilingual Matters.
Hinkel, E. 2001. Building Awareness and Practical Skills to Facilitate CrossCultural Communication. In M.Celce-Murcia (Ed.). Teaching English as a Second or Foreign Language. Boston: Heinle \& Heinle.

Hinkel, E. 1996. Culture in Second Language Teaching and Learning. Cambridge: Cambridge University Press.

Hymes, D. 1996. Ethnography, Linguistics, Narrative Inequality. Bristol, PA: Taylor and Francis.

Jesperson, O. 1904. How to Teach a Foreign Language. London: George Allen and Unwin, Ltd.

Lafayette, R. 1988. Integrating the Teaching of Culture Into the Foreign Language Classroom. In A.J. Singerman (Ed.). Toward a New Integration of Language and Culture. Reports of the Northeast Conference on the Teaching of Foreign Languages. Middlebury, VT: Northeast Conference 1988.

Lafayette, R. 1978. Teaching Culture: Strategies and Techniques. Language in Education: Theory and Practice. Series No. 11. Washington, DC: Center for Applied Linguistics.

Simon, P. 1980. The Tongue-tied American. New York: Continuum.

Slager, W.R. 1978. Creating Contexts for Language Practice. In E. Joiner and P.Westphal (Eds.). Developing Communication Skills. Rowley, MA: Newbury House.

Standards. 1996. Standards for Foreign Language Learning: Preparing for the $21^{\text {st }}$ Century. National Standards in Foreign Language Education Project, 1996.

Stern, H.H. 1990. Analysis and Experience as Variables in Second Language Pedagogy. In B. Harley, P. Allen, J. Cummins, and M. Swain (Eds.). The Development of Second Language Proficiency. Cambridge: Cambridge University Press.

Widdowson, H.G. 1978. Teaching Language as Communication. Oxford: Oxford University Press. 